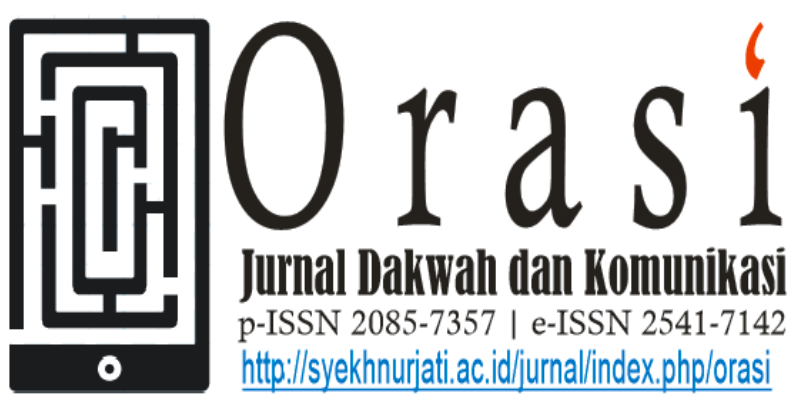

Volume 12 No. 2 Desember 2021

\title{
KAJIAN SEMIOTIKA ROLAND BARTHES PADA TAYANGAN 'KEADILAN UNTUK PARA PENGHAYAT' DI METRO TV
}

\section{ROLAND BARTHES' SEMIOTIC THEORY ON METRO TV'S "KEADILAN UNTUK PARA PENGHAYAT"}

\author{
Ahmad Sugeng Riady \\ Jurusan Studi Agama-Agama, UIN Sunan Kalijaga Yogyakarta \\ e-mail: ahmadsugengriady@gmail.com
}

\begin{abstract}
ABSTRAK
Artikel ini membahas tentang kepentingan dari sebuah media dalam meliput penghayat kepercayaan. Di satu sisi, Indonesia memiliki ratusan kelompok penghayat kepercayaan lokal yang secara eksistensi dibedakan dengan enam agama resmi yang telah diakui pemerintah. Sementara di sisi lain, media menjadi instrumen untuk mendistribusikan informasi dengan kepentingan tertentu. Berangkat dari hal itu, artikel ini bertujuan untuk mengkaji tentang tanda-tanda yang terdapat pada tayangan 'Keadilan untuk Para Penghayat' yang diproduksi oleh Metro TV. Tayangan ini menggunakan metode kualitatif deskriptif dengan pendekatan semiotika. Adapun analisis artikel ini menggunakan teori semiotika Roland Barthes dengan memperhatikan tanda, penanda, dan petanda yang kemudian dilihat makna denotasi dan konotasi. Makna-makna ini dilihat sebagai upaya rekonstruksi yang dilakukan oleh Metro TV terhadap para penghayat kepercayaan lokal. Adapun hasilnya diperoleh bahwa tayangan tersebut diproduksi oleh Metro TV memiliki dua kepentingan yang saling berkaitan, yakni yang pertama mengenai kesadaran multikultural. Kepercayaan lokal dinilai sebagai fakta yang tidak dapat dinegasikan dalam kehidupan umat beragama di Indonesia. Kemudian yang kedua berkaitan dengan toleransi yang belum melibatkan kelompok penghayat kepercayaan lokal, baik dalam konteks wacana, pengambilan kebijakan, sampai pada bentuk aplikatif pembangunan nasional. Artikel ini juga menjadi kontribusi dari saling silang wacana berkaitan dengan studi agama-agama dan culture studies.
\end{abstract}

Kata Kunci: Media, Agama, Penghayat Kepercayaan Lokal 


\begin{abstract}
This study discusses the interest of media in covering the life of creed believers. On one hand, Indonesia has hundreds of followers of local beliefs that are set aside from the six religions officially recognized by the government. While on the other hand, the media become instruments to distribute information with certain significances. Departing from that, this study aims to examine the signs contained in 'Keadilan untuk Para Penghayat', a show produced by Metro TV. This study used a descriptive qualitative method with a semiotic approach. To analyze the data, this study used Roland Barthes' semiotic theory by examining the signs, signifiers, and signifieds which were then seen from the denotative and connotative meanings. These meanings were considered as a reconstruction effort carried out by Metro TV for the followers of local beliefs. The results present that the show produced by Metro TV had two interrelated significances. The first significance is regarding multicultural awareness. Local beliefs are considered a fact that cannot be negated in the life of people with religions and beliefs in Indonesia. Then the second relates to tolerance which does not involve local belief groups, be it in the context of discourse, policy making, or the applicable form of national development. This study is also a contribution to cross-discourse regarding the study of religions and cultural studies.
\end{abstract}

Keywords: Media, Religion, Local Believers

\section{Pendahuluan}

Agama memiliki peran yang cukup signifikan pada kehidupan manusia. Tanpa adanya agama, manusia akan mengalami berbagai kesulitan untuk menjalani kehidupan. Sebagaimana diungkapkan oleh Radcliff Brown, bahwa agama diposisikan sebagai tempat bernaung bagi umatnya (Soehada, 2014). Pernyataan ini menegaskan bahwa manusia memiliki kecenderungan untuk menyandarkan diri mereka pada suatu zat yang berada di luar diri mereka. Zat inilah yang dianggap memiliki kekuatan luar biasa, sehingga secara tidak langsung, mampu membantu permasalahan hidup mereka. Dalam hal ini, manusia menyatakan dirinya sebagai makhluk tidak berdaya yang senantiasa pasti memerlukan kekuatan dari zat yang bersifat adikodrati.
Dalam konteks sosio-kultural di Indonesia, agama dapat dikategorikan ke dalam dua kelompok umum yaitu, pertama kategori agama yang resmi diakui seperti Islam, Kristen, Hindu, Budha. Kemudian yang kedua adalah agama lokal yang masih menjunjung tinggi nilai kearifan lokal (Santosa, 2012). Perbedaan keduanya dapat diketahui melalui indikasi bahwa agama yang diakui secara resmi berpedoman pada kitab suci dan wahyu yang diturunkan dan didistribusikan melalui nabi. Adapun agama lokal masih diindikasikan melalui distribusi ajaran yang cenderung melestarikan tradisi oral dengan bahasa lokal, yang disampaikan secara turun-temurun dari satu generasi ke generasi berikutnya. Kegiatan keagamaannya juga masih terikat dengan mata pencaharian dan kegiatan sosial ekonomi lainnya. 
Secara fungsional agama juga memberikan identitas bagi penganutnya (Soehada, 2014). Identitas ini dinilai berharga bagi seseorang penganut agama di dalam sistem sosialnya. Sebab dengan adanya identitas tersebut, antara penganut agama yang satu dengan lainnya dapat diidentifikasi secara jelas. Secara administratif, identitas keagamaan ini juga menjadi dasar bagi pemangku kebijakan untuk memenuhi hak-hak setiap penganut agama sebagai warga negara yang sah.

Di Indonesia sendiri, sejak masa orde baru hanya mengakui enam agama yakni Islam, Protestan, Katolik, Hindhu, Budha, dan belakangan ditambah Kong $\mathrm{Hu}$ Chu yang notabene merupakan agama-agama dengan kuantitas penganut yang relatif cukup banyak. Di luar itu, masih ada agama lokal yang bertahan dan tumbuh subur di tengah-tengah masyarakat hingga saat ini. Pengakuan pemerintah atas enam agama ini memicu berbagai permasalahan. Prototipenya seperti ketika seorang penganut agama lokal tidak diakui oleh negara, maka kolom agama dalam Kartu Tanda Penduduk (KTP), pada bagian agama dikosongi karena agama yang dianut di luar enam agama yang telah diresmikan oleh pemerintah. Dengan kosongnya kolom agama ini, mereka menjadi sulit untuk mengakses hak-haknya sebagai warga negara, seperti hak untuk memperoleh pendidikan dan atau kesehatan yang layak (Gardanita dan Widodo, 2020).

Adapun di sisi lain, media dalam kurun beberapa tahun belakangan ini berkembang cukup pesat. Media-media yang dulu basisnya dicetak, sekarang sudah beralih menjadi media online dengan kecepatan distribusi dan akses yang relatif cukup mudah. Beragam berita dan informasi dari lokal, nasional, bahkan internasional dapat ditemukan dengan mudah melalui media (Riady, 2020), termasuk juga berita tentang penganut agama lokal yang diproduksi dan didistribusikan oleh beberapa media. Secara tidak langsung, media juga memiliki andil dalam membentuk konstruksi dari masyarakat sebagai konsumennya, termasuk salah satu media itu adalah Metro TV.

Metro TV sendiri merupakan salah satu stasiun televisi swasta yang mulai berdiri pada tahun 2000-an. Di tahun-tahun awal berdirinya, Metro TV belum memiliki wilayah garapan yang jelas. Maka pada tahun 2010, pihak manajemen melakukan redefinisi ulang mengenai orientasi berdirinya Metro TV. Akhirnya Metro TV memilih untuk menggarap wilayah berita sebagai program utama atau Top of Mind yang sekaligus membedakannya dengan stasiun televisi swasta lainnya. Salah satu diantara sekian program berita yang diproduksi oleh Metro TV adalah Melawan Lupa.

Program Melawan Lupa oleh Metro TV ini diperuntukkan untuk membahas berbagai macam peristiwa sejarah yang ada di negeri ini. Akan tetapi narasi yang disampaikan oleh Metro TV sebagai pihak produksi, berbeda dengan narasi yang ada pada umumnya, baik itu di literatur maupun yang diajarkan di bangku pendidikan. Berikut keterangannya: 
Melawan Lupa adalah sebuah program acara dokumenter di Metro TV yang mengulas berbagai peristiwa bersejarah yang turut membentuk mengenai sebuah entitas yang hari ini dikenal sebagai Indonesia. Tayangan ini, seperti judulnya, sedikit-banyak berupaya menjadi narasi tanding atas apa-apa yang selama ini mendefinisikan diri sebagai sejarah nasional Indonesia. Dengan menyajikan narasi-narasi kecil di balik peristiwa-peristiwa besar yang terjadi, Melawan Lupa ditujukan bagi siapa saja yang menolak lupa atas segala hal yang pernah terjadi dalam sejarah Indonesia. ${ }^{1}$

Program Melawan Lupa ini secara tidak langsung juga memiliki agenda atau kepentingan tertentu, yang dalam tahap lanjut dapat turut ambil bagian dalam merekonstruksi ulang pemahaman masyarakat mengenai sesuatu, termasuk tayangan 'Keadilan untuk Para Penghayat'. Tayangan ini sengaja dipilih oleh peneliti dengan melihat pada kondisi aktual yang dialami oleh para penghayat kepercayaan di berbagai macam daerah di negeri ini. Pada umumnya para penghayat kepercayaan ini sudah membaur menjadi bagian dari masyarakat, bahkan di beberapa tempat justru menjadi aset yang dapat dikembangkan dan destinasi wisata. Di satu sisi para penghayat kepercayaan ini tetap mendapatkan perlakuan yang timpang dari pemangku kebijakan, jika dibandingkan dengan umat yang menganut enam agama resmi.

Berangkat dari hal itu, peneliti merasa tertarik untuk menindaklanjutinya dengan

${ }^{1}$ Diakses dari
https://www.metrotvnews.com/program/melawan-
lupa pada 04 Januari 2021

penelitian yang mendalam. Maka dari itu, artikel ini mencoba untuk melihat seperti apa dibalik tanda-tanda yang terdapat pada tayangan 'Keadilan untuk Para Penghayat' yang diproduksi oleh Metro TV. Lebih lanjut lagi, peneliti akan melihat kepentingan, pesan, atau narasi tandingan dari Metro TV terhadap penganut penghayat kepercayaan yang ada di negeri ini. Hal ini penting, mengingat, penganut penghayat kepercayaan sendiri baru belakangan mendapatkan haknya secara legal formal.

\section{Metode dan Teori}

Metode pada artikel ini menggunakan metode kualitatif deskriptif. Adapun penelitian kualitatif sendiri merujuk pada Moeloengmerupakan penelitian yang dilakukan secara alamiah oleh si peneliti dengan mempertimbangkan keadaan alamiah dari subjek dan atau objek yang diteliti (Moelong, 2014). Penelitian jenis ini berupaya untuk menafsirkan makna peristiwa atau interaksi antar manusia dalam situasi tertentu menurut perspektif peneliti, dengan orientasi untuk memahami subjek dan atau objek penelitian secara mendalam (Gunawan, 2013).

Pendekatan yang digunakan pada artikel ini menggunakan pendekatan semiotika, yakni pendekatan untuk melihat pesan atau sesuatu yang berada di balik apa yang ditampilkan dan atau diproduksi oleh media. Memang pada dasarnya (dalam tinjauan ilmu sosial-antropologi), manusia merupakan makhluk yang kerap memproduksi tanda atau simbol-simbol tertentu (Hendro, 2020). Tanda atau simbol ini juga digunakan 
sebagai alat komunikasi, baik komunikasi yang sifatnya transenden-sakral maupun komunikasi yang cenderung profan-horizontal.

Kemudian teori yang digunakan penulis sebagai pisau analisis adalah teori semiotika Roland Barthes. Dalam teori tersebut, Roland Barthes membaginya menjadi tiga bagian yang saling berkaitan. Bagian pertama sign (tanda), yakni sesuatu yang dilihat oleh mata manusia dari permukaannya saja. Kemudian bagian kedua signifier (penanda), yakni sesuatu yang dipahami oleh manusia dari sign (tanda) tersebut. Bagian terakhir signified (petanda), yakni konsep tertentu yang berada di balik sign (tanda) dan signifier (penanda) (Purwanto dan Muzir, 2018).

Adapun denotasi menurut Roland Barthes ada pada tataran pertama, yakni hubungan antara signifier (penanda) dan signified (petanda). Keduanya menghasilkan sign (tanda) yang memiliki makna langsung, terang, jelas, dan tegas. Sign (tanda) di tataran pertama ini, akan berubah menjadi signifier (penanda) pada tataran kedua. Hubungan signifier (penanda) dan signified (petanda) pada tataran kedua akan menghasilkan sign (tanda) yang sifatnya konotasi, dalam arti memiliki makna yang tidak langsung, samar, dan tidak terlalu baku. Lebih lanjut lagi, Roland Barthes menyebut makna pada sign (tanda) pada tataran kedua ini sebagai mitos. Adapun mitos versi Roland Barthes berbeda dengan definisi mitos pada umumnya. Roland Barthes mendefinisikan mitos sebagai sebuah sistem komunikasi yang memiliki pesan dalam konteks tertentu (Purwanto dan Muzir, 2018).

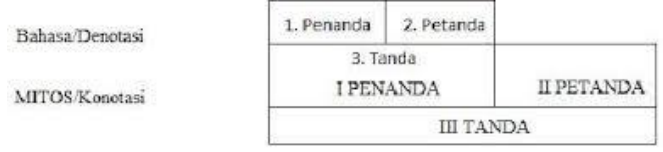

Gambar 1. Skema Semiotika Roland Barthes

Berkaitan dengan sumber data pada artikel ini dipilah menjadi dua, yakni data primer dan data sekunder (Sofia, 2017). Data primer diambil dari tayangan 'Keadilan untuk Para Penghayat' dari program Melawan Lupa yang diproduksi oleh Metro TV di website resminya. Kemudian data sekunder akan diambil oleh peneliti melalui berbagai macam literatur, baik buku, jurnal, dan koran. Datadata yang sudah terkumpul itu, akan dipilah, diseleksi, dan digunakan sesuai dengan kebutuhan untuk menjawab problem yang diajukan peneliti.

\section{Hasil dan Pembahasan}

\subsection{Tanda pada Tayangan Keadilan untuk Para Penghayat}

Program Melawan Lupa yang diproduksi oleh Metro TV ini tayang setiap hari Selasa jam 22.30. Satu kali tayangan berdurasi 30 menit dengan tiga sampai lima kali segmen. Tayangan terakhir pada program Melawan Lupa ini berjudul 'Jejak Para Pemimpin Jakarta' yang dipublish pada tanggal 20 Juni 2020 jam 20:18:03 di website resmi Metro TV. Adapun tayangan 'Keadilan untuk Para Penghayat' yang menjadi topik penelitian pada artikel ini terdiri dari tiga sesi yang dipublish pada tanggal 09 Januari 2018 dini hari. 
Dalam konteks penelitian ini, beberapa adegan pada tayangan 'Keadilan untuk Para Penghayat' dipilah sesuai dengan kebutuhan. Adegan tersebut dianalisis dengan melihat makna denotasi dan konotasinya. Terkait itu, peneliti hanya mengambil adegan pelaku penghayat kepercayaan lokal dari pakaiannya, foto Kartu Tanda Penduduk (KTP), pendidikan anak-anak penghayat kepercayaan lokal, dan ritual penghayat kepercayaan lokal.

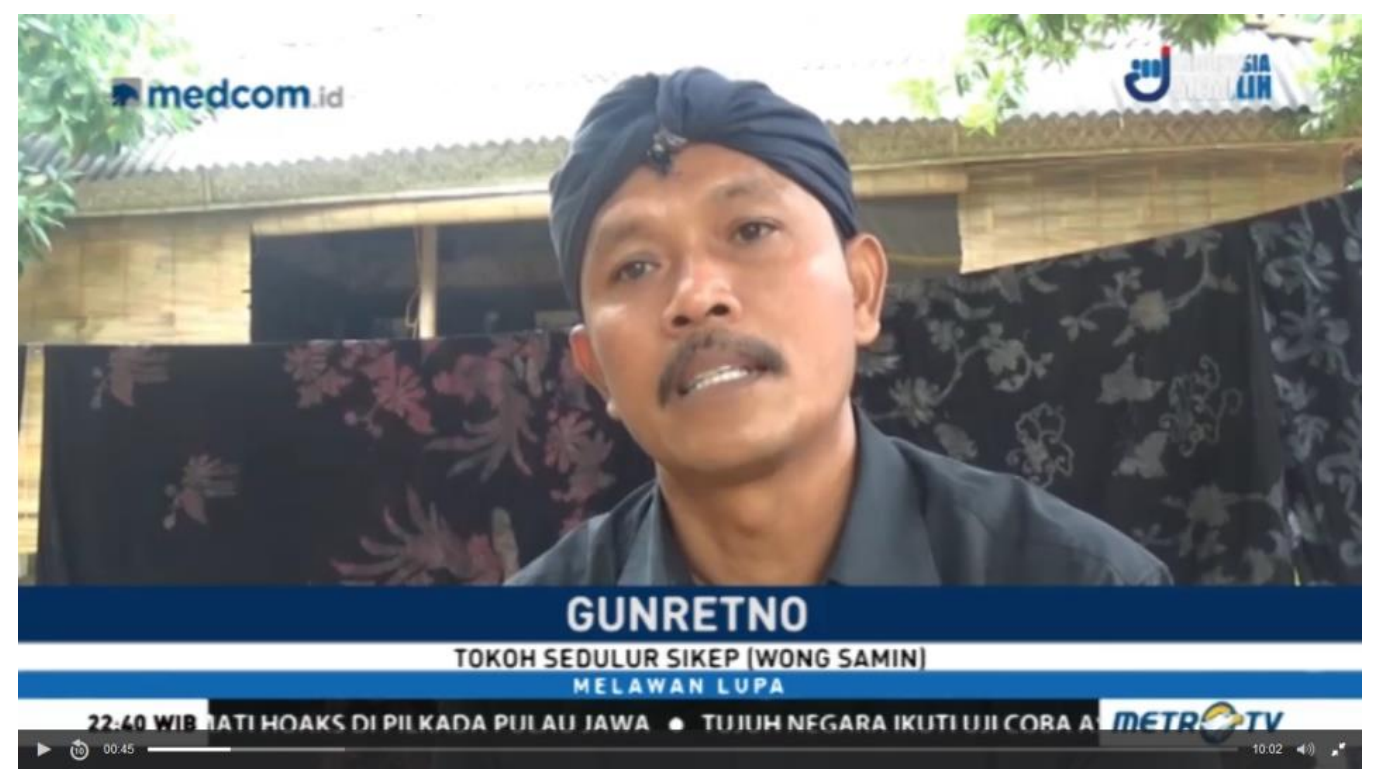

Gambar 2. Pakaian penganut penghayat kepercayaan

Sumber: https://www.metrotvnews.com/play/b2vUdwGX-keadilan-untuk-para-penghayat-kepercayaan-2

a. Pakaian penganut penghayat kepercayaan

Pada gambar 2 di atas terdapat pada tayangan sesi kedua menit ke 00:49 - 01:13. Pada tayangan tersebut ada tiga unsur sekaligus, yakni visual, teks, dan audio. Unsur visual dapat dilihat bahwa di gambar tersebut ada salah satu penganut penghayat kepercayaan lokal yang berpakaian serba hitam, termasuk tutup kepalanya. Di belakangnya ada kain dengan motif tertentu yang berwarna hitam.

Kemudian unsur teks meliputi nama penganut penghayat kepercayaan tersebut yakni Gunretno. Di gambar tersebut ia ditulis sebagai tokoh Sedulur Sikep (Wong Samin). Ada juga teks di bawah nama tersebut, yang disebut dengan berita berjalan dalam sebuah tayangan. Di sebelah kiri teks berita berjalan itu ada jam, sedangkan di sebelah kanan ada logo Metro TV. Kemudian di sudut kiri atas ada tulisan medcom.id, dan di sudut kanan atas ada tulisan Indonesia Memilih. Teks-teks ini didominasi oleh warna biru putih. Berikut terkait unsur audio, "Berkaitan agama dipahami, bahwa agama itu ageman. (Agama) itu ke arah pribadi. Jadi ini tidak harus diakui atau diperjuangkan untuk diakui, yang penting apa tujuan (dari) agama itu dilakukan secara konkret. Itu yang lebih penting." 


\begin{tabular}{|c|c|c|}
\hline 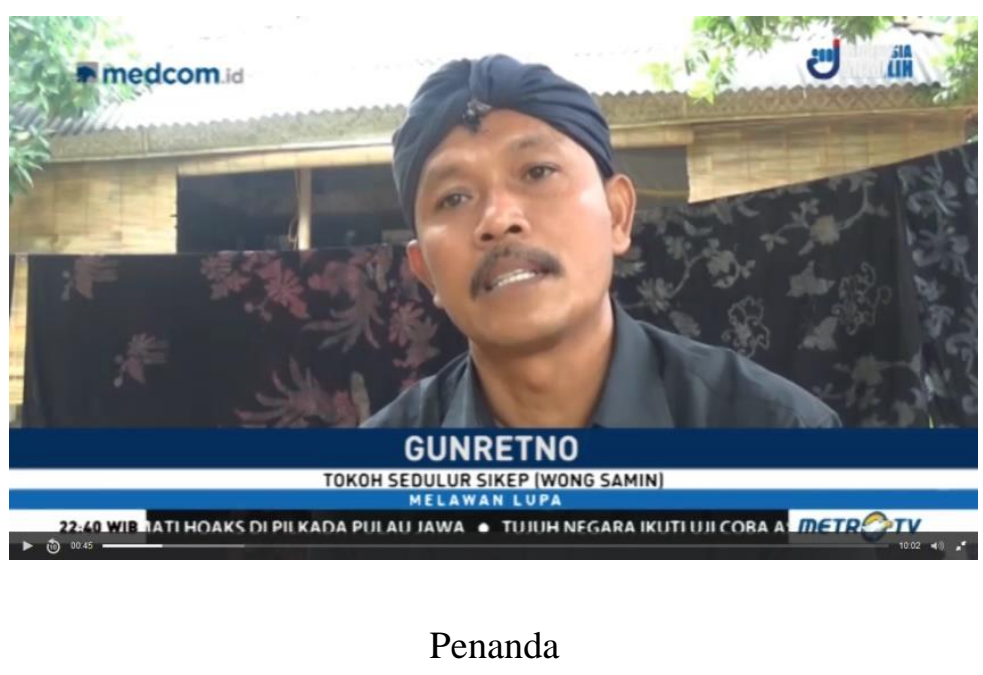 & $\begin{array}{l}\text { Penganut } \\
\text { kepercayaan } \\
\text { lokal sedang } \\
\text { berbicara dengan } \\
\text { menggunakan } \\
\text { pakaian hitam. } \\
\text { Petanda }\end{array}$ & \\
\hline $\begin{array}{l}\text { Pakaian itu sebagai ciri-ciri dirinya menjadi bagian dari } \mathrm{p} \\
\text { kepercayaan. } \\
\text { Tanda } \\
\text { (PENANDA) }\end{array}$ & nganut penghayat & $\begin{array}{l}\text { Pakaian dengan } \\
\text { rapi dan } \\
\text { tertutup. } \\
\text { (PETANDA) }\end{array}$ \\
\hline $\begin{array}{l}\text { Eksistensi sebagai penganut penghayat keperc } \\
\qquad \text { (TANDA) }\end{array}$ & yaan lokal yang taa & \\
\hline
\end{tabular}

Pada bagan di atas dapat diketahui bahwa makna denotasinya, pakaian yang berwarna hitam itu sebagai ciri-ciri dari penganut penghayat kepercayaan Sedulur Sikep (Wong Samin). Sama halnya dengan umat Islam sebagai agama resmi yang memiliki pakaian sebagai identitasnya seperti sarung, peci, kain ihram untuk haji, atau menggunakan mukena bagi perempuan ketika mendirikan shalat. Kemudian makna konotasinya adalah bentuk pernyataan sikap dari penganut penghayat kepercayaan lokal bahwa dirinya atau kelompoknya itu ada. Kendati mereka tidak menganut salah satu dari enam agama resmi yang diakui di negeri ini, mereka tetap menunjukkan perilaku sebagai manusia beragama yang taat. Indikasinya ada pada pakaian lengkap yang dipakai oleh Sedulur Sikep (Wong Samin) dalam keseharian. 


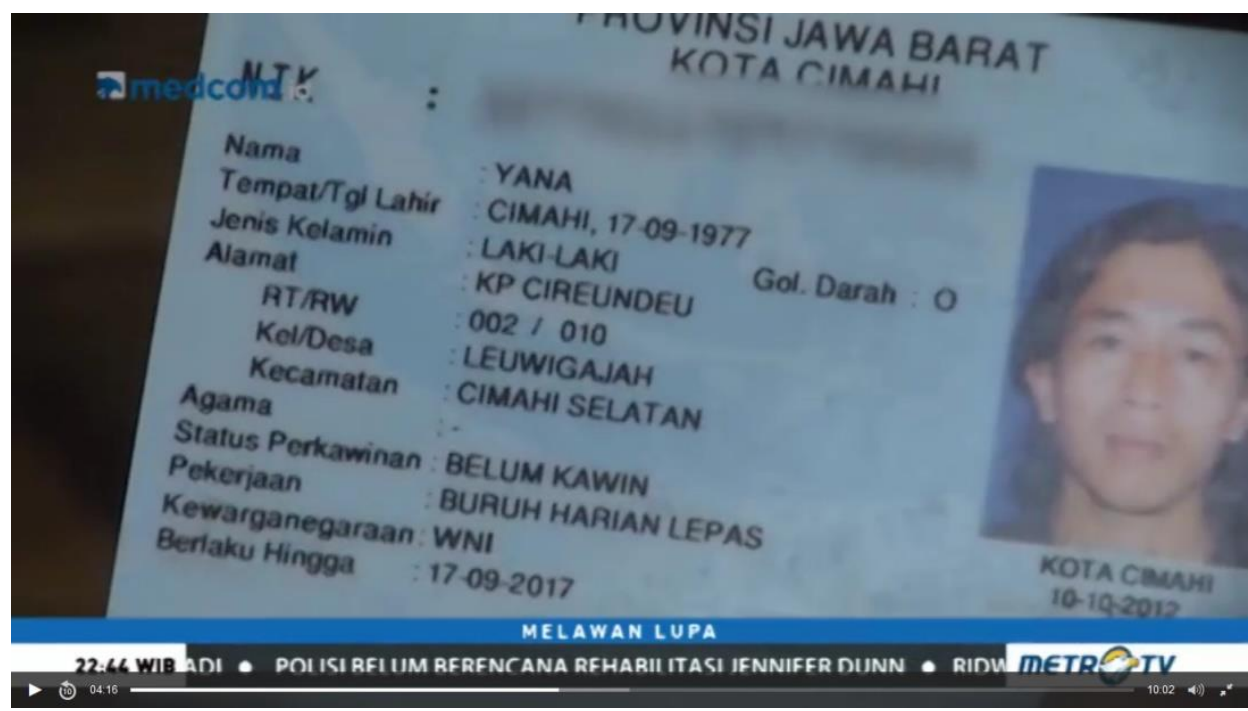

Gambar 3. Kartu Tanda Penduduk milik salah satu anggota penganut penghayat kepercayaan. Sumber https://www.metrotvnews.com/play/b2vUdwGX-keadilan-untuk-para-penghayat-kepercayaan-2

b. Foto Identitas Kependudukan

Pada gambar 3 di atas terdapat pada tayangan sesi kedua di menit ke 04:14 - 04:22. Pada tayangan tersebut terdapat tiga unsur yakni visual, teks, dan audio. Unsur visualnya ada pada gambar Kartu Tanda Penduduk (KTP) berwarna biru. Di dalam Kartu Tanda Penduduk (KTP) itu terdapat foto pemiliknya di sebelah kanan.

Unsur teks meliputi nama pemilik, alamat, profesi, kolom agama yang kosong, dan masa berlaku Kartu Tanda Penduduk (KTP) tersebut. Ada juga teks di bawah nama tersebut, yang disebut dengan berita berjalan dalam sebuah tayangan. Di sebelah kiri teks berita berjalan itu ada jam, sedangkan di sebelah kanan ada logo Metro TV. Kemudian di sudut kiri atas ada tulisan medcom.id. Teksteks ini didominasi oleh warna biru putih. Adapun audionya sebagai berikut, "Praktik diskriminasi yang dihadapi oleh penghayat kepercayaan, biasanya terjadi ketika mereka mengurusi administrasi birokrasi seperti mengurus surat perkawinan atau mengurus surat kerja di instansi pemerintahan". 


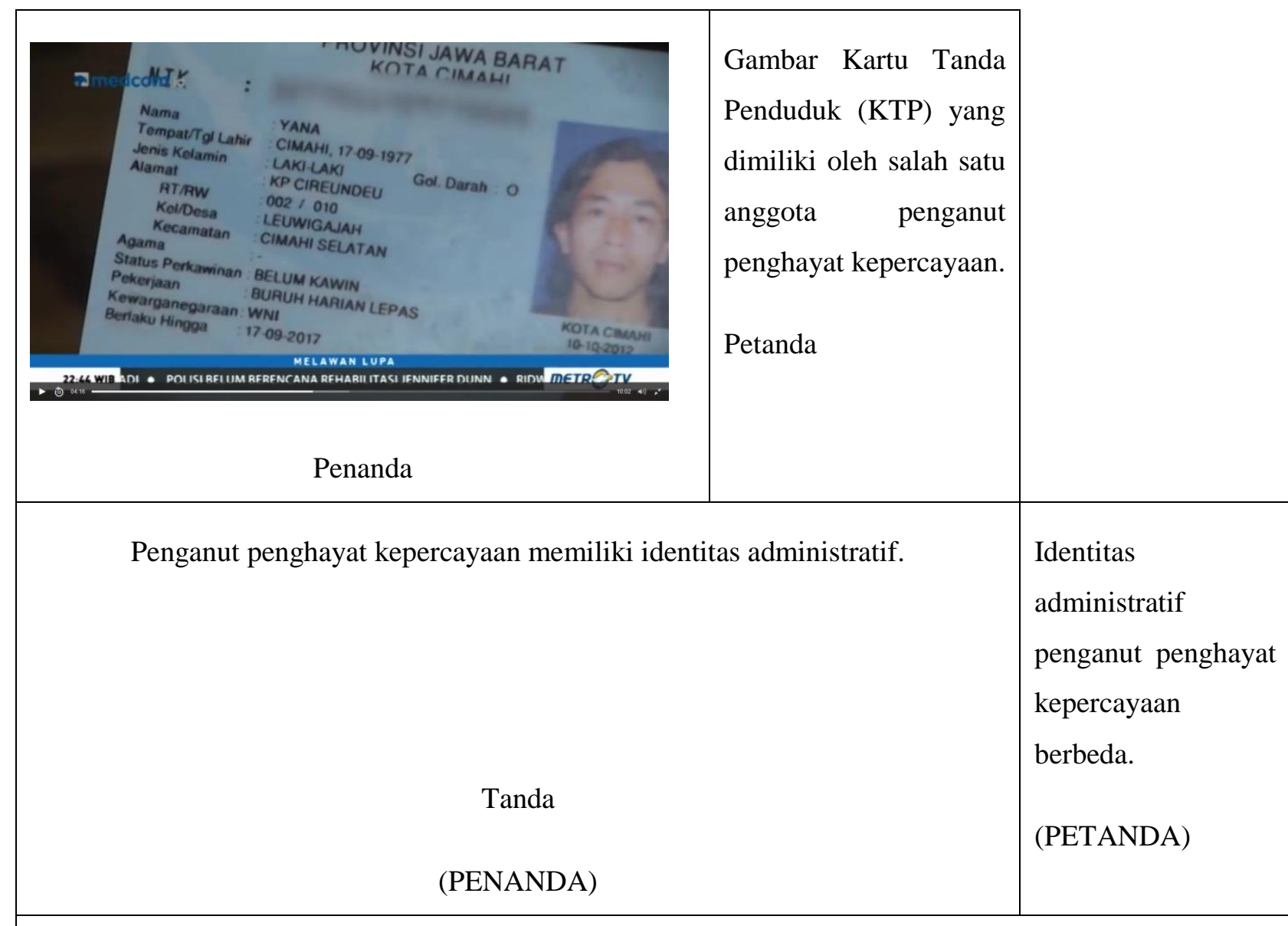

Penganut penghayat kepercayaan rawan terdiskriminasi melalui identitas administrasi yang berbeda.

(TANDA)

Adapun makna denotasi dari bagan di atas ialah setiap anggota penganut penghayat kepercayaan dapat memiliki identitas secara administratif, yakni memiliki Kartu Tanda Penduduk (KTP). Secara umum identitas adminitratif ini sama dengan yang dimiliki oleh penganut enam agama yang diakui resmi oleh pemerintah. Akan tetapi, identitas milik penganut penghayat kepercayaan berbeda, karena pada bagian kolom agama dikosongi. Berangkat dari perbedaan itu, makna konotasinya ditemukan bahwa penganut penghayat kepercayaan lokal dapat dihadapkan pada diskriminasi yang menjurus pada pengabaian hak-haknya sebagai warga negara (Humaidi, 2020). Padahal jika kembali pada landasan konstitusional dan ideal yang dimiliki oleh negeri ini, tidak ada legitimasi yang menegaskan para penganut penghayat kepercayaan lokal boleh atau sah-sah saja untuk didiskriminasi sampai pada pengabaian hak-haknya. 


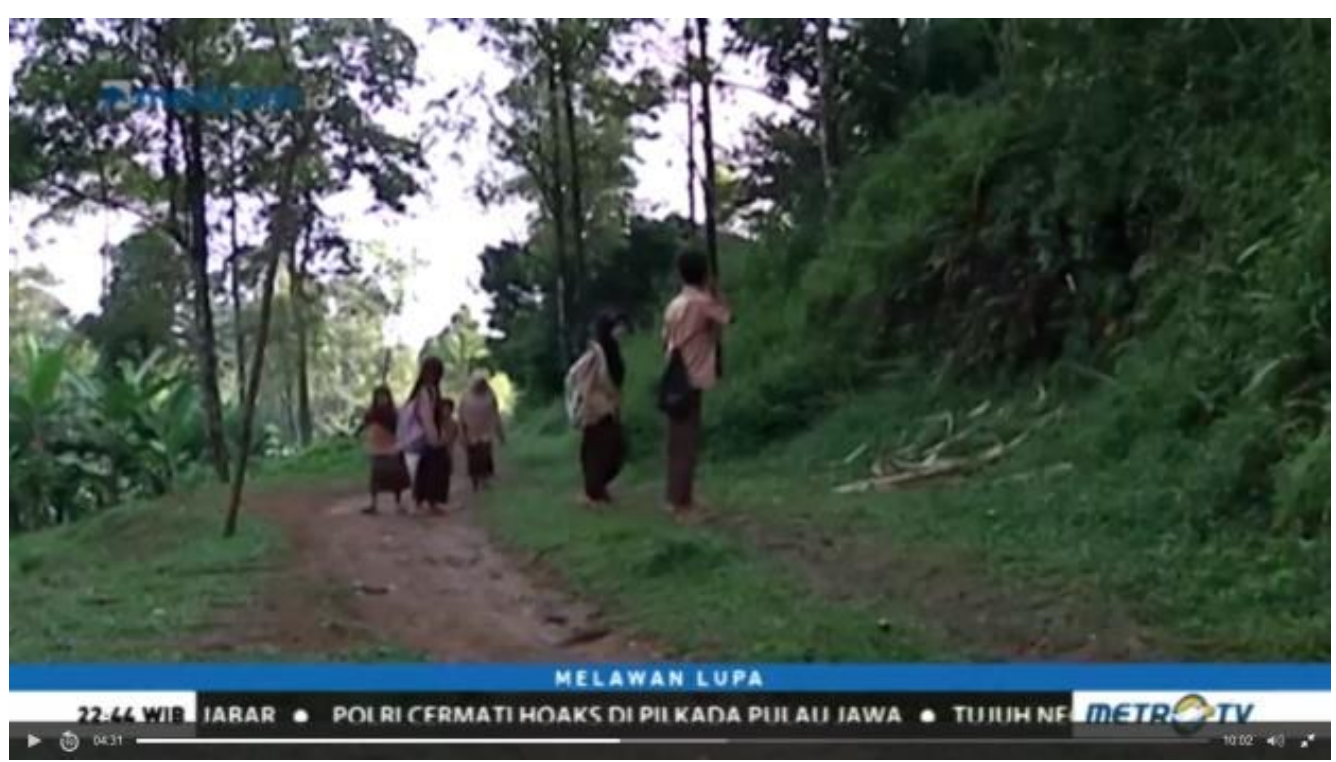

Gambar 4. Potret anak penghayat kepercayaan lokal yang berangkat sekolah Sumber https://www.metrotvnews.com/play/b2vUdwGX-keadilan-untuk-para-penghayat-kepercayaan-2

c. Pendidikan anak-anak penghayat kepercayaan lokal

Pada gambar 4 di atas terdapat di tayangan sesi kedua menit ke 04:26 - 04:33. Pada tayangan tersebut, terdapat dua unsur yakni visual dan audio. Unsur visualnya dapat dilihat ada enam anak, dengan dua laki-laki dan empat perempuan berhijab yang sedang berangkat ke sekolah memakai seragam pramuka. Mereka melintasi jalan setapak yang belum beraspal, dengan kanan kiri masih terlihat pemandangan yang cukup asri dan alami. Ada juga teks di bawah nama tersebut, yang disebut dengan berita berjalan dalam sebuah tayangan. Di sebelah kiri teks berita berjalan itu ada jam, sedangkan di sebelah kanan ada logo Metro TV. Kemudian di sudut kiri atas ada tulisan medcom.id. Teks-teks ini didominasi oleh warna biru putih. Berikut unsur audionya, "Selain itu, praktik diskriminasi juga menimpa anak-anak para pelaku penghayat kepercayaan yang dipaksa untuk memilih mengikuti pelajaran agama tertentu di sekolah". 


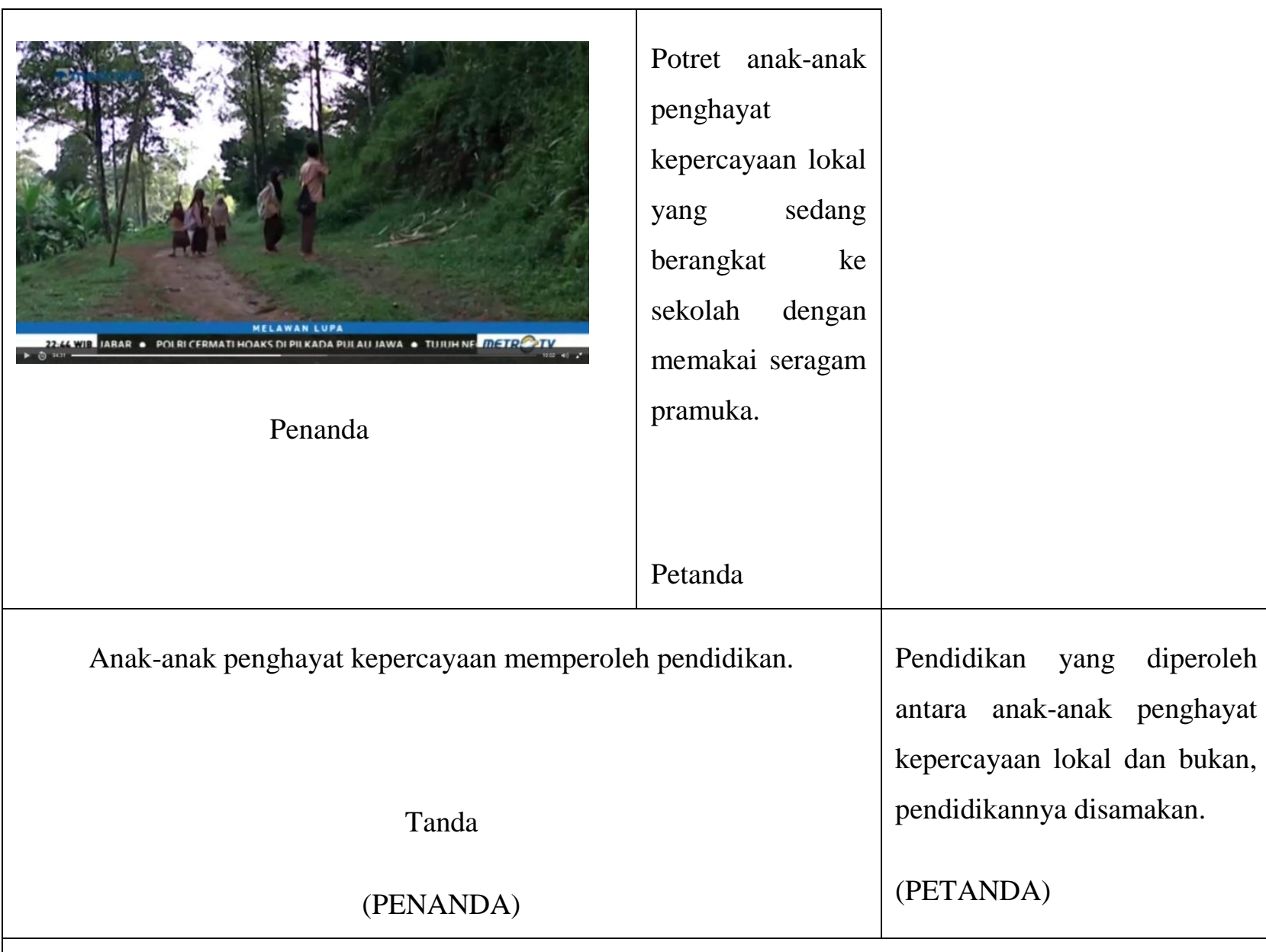

Ada penggiringan sistemik supaya anak-anak penghayat kepercayaan lokal beralih menganut agama resmi yang diakui pemerintah

(TANDA)

Pada bagan di atas, makna konotasinya, pendidikan semacam ini justru denotasinya didapati bahwa anak-anak menjadi upaya dari pemerintah, yang secara penghayat kepercayaan lokal juga memperoleh pendidikan seperti anak-anak dari penganut agama resmi pemerintah. Mereka bersekolah di sekolah yang sama, seragam dan mata pelajaran yang diperoleh juga sama serta berpeluang untuk menjadi terbaik di dalam kelas. Pada titik ini ada kesan kesetaraan dan pemenuhan hak diperoleh oleh generasi atau anak-anak penganut penghayat kepercayaan lokal. Akan tetapi jika dilihat dari makna tidak langsung mengarahkan anak-anak penghayat kepercayaan lokal agar beralih dan menganut agama yang telah diakui resmi. Dalam konteks pendidikan agama utamanya, anak-anak penghayat kepercayaan lokal akan diajari agama-agama yang telah diakui dan masuk dalam kurikulum (Baso, 2006). Sementara agama, sejarah kemunculan agama sampai pada ritual dari agamanya sendiri tidak diajarkan di sekolah. 


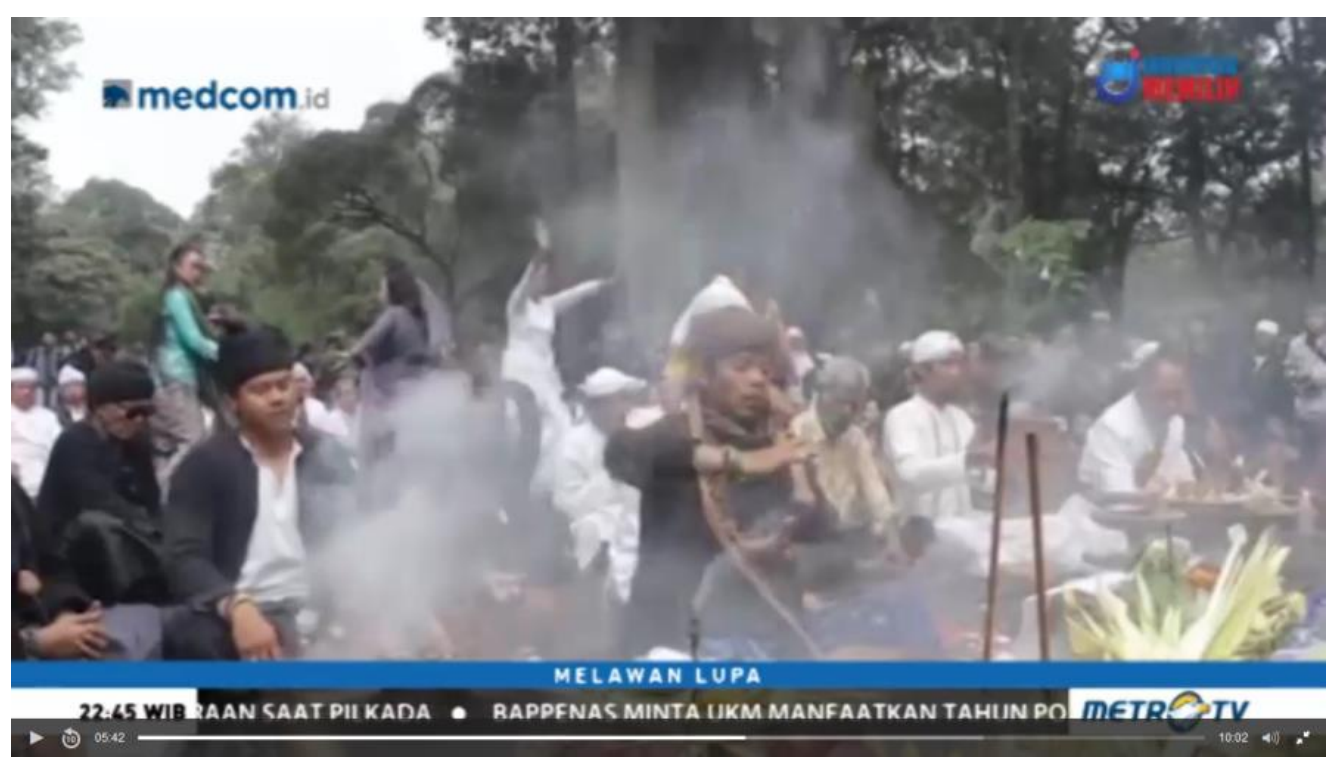

Gambar 5. Penganut penghayat kepercayaan lokal melakukan ritual Sumber https://www.metrotvnews.com/play/b2vUdwGX-keadilan-untuk-para-penghayatkepercayaan-2

d. Ritual penghayat kepercayaan lokal

Pada gambar 5 di atas, terdapat di tayangan sesi kedua menit ke 05:34 - 05:44. Pada gambar di atas juga terdapat dua unsur, yakni unsur visual dan unsur audio. Unsur visual dapat dilihat pada sekelompok penganut penghayat kepercayaan yang sedang melakukan ritual. Ada yang menggunakan pakaian hitam, ada juga yang putih lengkap dengan tutup di kepala. Terlihat juga di gambar tersebut asap yang berasal dari dupa dibakar dan disertai dengan makanan. Semua pria terlihat duduk, sementara itu ada tiga perempuan yang berdiri dengan posisi menari. Kemudian di pinggir terdapat orang yang sedang menonton ritual tersebut. Ada juga teks di bawah nama tersebut, yang disebut dengan berita berjalan dalam sebuah tayangan. Di sebelah kiri teks berita berjalan itu ada jam, sedangkan di sebelah kanan ada logo Metro TV. Kemudian di sudut kiri atas ada tulisan medcom.id. Teks-teks ini didominasi oleh warna biru putih. Kemudian untuk unsur audionya sebagai berikut, “... Meski demikian teknis pencantuman aliran kepercayaan dalam kolom agama di KTP masih membutuhkan kajian dan persiapan yang lebih rinci”. 


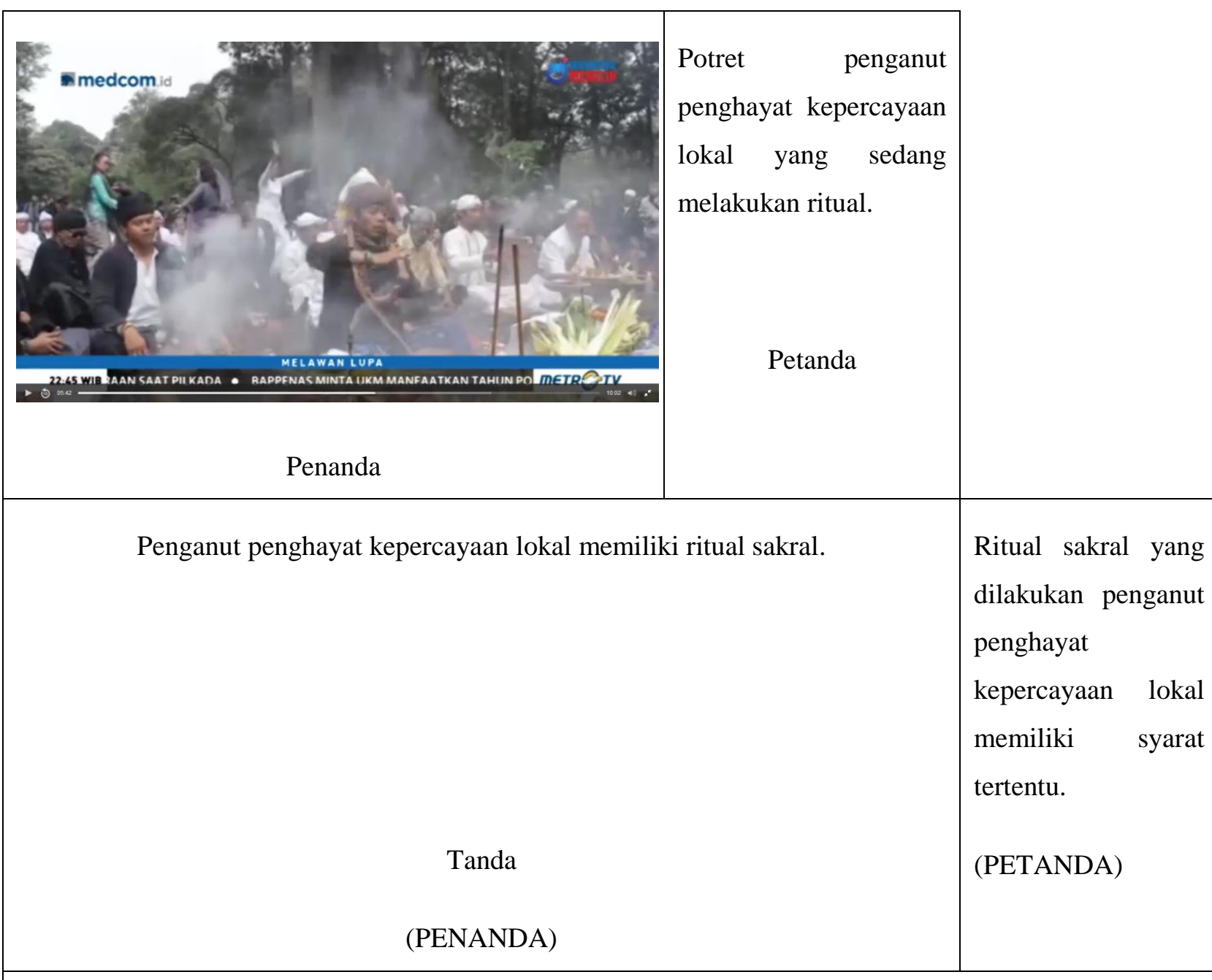

Penganut penghayat kepercayaan lokal memiliki ritual sakral sebagai cara untuk mendekatkan diri kepada Maha Pencipta.

(TANDA)

Dari bagan di atas, didapati makna denotasinya ialah penganut penghayat kepercayaan lokal memiliki ritual-ritual sakral. Di satu sisi, ritual tersebut juga memerlukan syarat tertentu seperti pakaian dan perangkat pendukung ritual seperti dupa yang dibakar dan makanan. Hal ini sama seperti umat Islam yang menunaikan shalat lima waktu di masjid, yang juga memerlukan syarat tertentu seperti adanya imam, pakaian menutup aurat, sajadah, dan pengeras suara untuk adzan. Lebih jauh jika dilihat makna konotasinya, akan didapati bahwa ritual tersebut juga memiliki nilai guna bagi si pelakunya. Salah satu nilai guna yang penting ketika dilakukannya sebuah ritual adalah sebagai upaya untuk mendekatkan diri, atau bertemu secara rohani antara si pelaku dengan Maha Pencipta, tidak terkecuali bagi penganut penghayat kepercayaan local (Muchimah dan Ulum, 2020). 


\subsection{Konstruksi Metro TV pada Tayangan 'Keadilan untuk Para Penghayat'}

Secara historis, keberadaan penganut penghayat kepercayaan lokal sudah ada sebelum negeri ini dideklarasikan sebagai negara yang merdeka. Bahkan jauh sebelum regulasi dibuat oleh pemangku kebijakan, penganut penghayat kepercayaan lokal telah tumbuh dan berkembang, baik dalam segi kuantitas maupun kualitas. Dari segi kualitas dapat dilihat pada konsepnya tentang memaknai kehidupan dan atau relasi dengan sesuatu yang dikodrati. Adapun dari sisi kuantitas, penganut penghayat kepercayaan lokal juga bertambah, minimal dilihat dari generasi yang datang setelahnya (Budijanto, 2016).

Akan tetapi sejak masa Orde Baru, para penganut penghayat kepercayaan lokal mulai dipinggirkan. Keberadaannya cenderung dinegasikan sebagai warga negara, jika tidak mau beralih menjadi penganut agama yang telah diakui resmi oleh pemerintah. Syamsul Maarif menilai ini sebagai keputusan politik. Penganut penghayat kepercayaan lokal yang mulanya tidak memiliki kuasa, daya, dan kepentingan politik, dijadikan sebagai korban yang pada saat itu, kondisi negeri ini sedang mengalami gejolak politik. Kondisi yang tidak menguntungkan penganut penghayat kepercayaan lokal ini dimulai sejak tahun 1978. Dari tahun itu sampai tahun 1998, kepercayaan bukan didefinisikan sebagai agama. $^{2}$ Akibatnya para penganut penghayat

\footnotetext{
${ }^{2}$ Diakses melalui website resmi Metro TV pada Rabu 06 Januari 2021,
}

kepercayaan lokal akan dianggap sebagai ateis yang berafiliasi pada Partai Komunis Indonesia (PKI) (Budijanto, 2016).

Adapun tayangan yang diproduksi oleh Metro TV, yang di satu sisi sebagai salah satu media yang memilih berita sebagai topik utamanya, dan di sisi lain berupaya menyuguhkan konsumen dengan narasi berbeda sebagai tandingannya, ingin menampilkan kembali eksistensi penganut penghayat kepercayaan lokal melalui tayangan di program Melawan Lupa. Tayangan ini menampilkan suara langsung dari pihak penganut penghayat kepercayaan lokal yang diwakili oleh pihak Sunda Wiwitan dan Sedulur Singkep (Wong Samin). Selain itu, tayangan ini juga diproduksi setelah judicial review yang diajukan oleh Nggay Mehang Tana, Pagar Demanra Sirait, Arnol Purba, dan Carlim terkait diskriminasi yang dialami karena pengosongan kolom agama pada Kartu Tanda Penduduk (KTP) dan Kartu Keluarga (KK). Judicial Review ini dikabulkan oleh Mahkamah Konstitusi (MK) pada 7 November 2017 (Humaidi, 2020).

Kendati secara legal konstitusional penganut penghayat kepercayaan lokal telah memperoleh legitimasi, namun secara faktual diskriminasi yang dialami masih tetap ada. Majelis Ulama Indonesia (MUI) melalui hasil rakernas ke-III, menilai keputusan Mahkamah Konstitusi (MK) telah melukai perasaan umat beragama. Sebab menurut kacamata Majelis Ulama Indonesia (MUI) agama tidak dapat disejajarkan dengan aliran kepercayaan. keadilan-untuk-para-penghayat-kepercayaan-1 
Berangkat dari fakta seperti itu, tayangan 'Keadilan untuk Para Penghayat' ini memiliki pesan atau kepentingan tertentu yang ingin disampaikan dari pihak produksi ke konsumen. Tanda-tanda yang dijelaskan mulai dari pakaian, foto Kartu Tanda Penduduk (KTP) yang kolom agamanya dikosongi, kondisi pendidikan anak-anak penghayat kepercayaan lokal, dan ritual penghayat kepercayaan lokal melahirkan dua pesan yang saling terkait, yakni pesan tentang kesadaran multikultural dan pentingnya toleransi.

Terkait multikultural, Bhikhu Parekh mendefinisikannya sebagai fakta kultural yang beranekaragam. ${ }^{3}$ Di Indonesia sendiri, fakta masyarakatnya juga multi, mulai dari multietnis, multi-agama, multi-bahasa, dan lainlain. Fakta yang seperti ini memang disadari, akan tetapi jarang menjadi pertimbangan dalam mengambil kebijakan legal formal (produk hukum), silang wacana dalam diskusi (diskursus), dan interes politis ketika suhu demokrasi mulai memanas dalam konteks lima tahunan.

Berkaitan dengan penganut penghayat kepercayaan lokal, mereka juga menjadi bagian dari masyarakat multikultural.

\footnotetext{
${ }^{3}$ Definisi multikulturalisme ini berangkat dari tiga jenis klasifikasi keanekaragaman yang dirumuskan oleh Bhikhu Parekh.Ketiga jenis klasifikasi tersebut yakni keanekaragaman subkultur, keanekaragaman perspektif, dan keanekaragaman komunal. Kendati keanekaragaman komunal menjadi topik dominan dalam multikulturalisme, namun dua sebelumnya juga menjadi bagian yang tidak dipisahkan. Bahkan terkadang keduanya menjadi perspektif lain dalam melihat fakta multikulturalisme. Bhikhu Parekh, Rethinking Multiculturalism Keberagaman Budaya dan Teori Politik (Yogyakarta: Penerbit Kanisius, 2012), hlm. 19-20
}

Keberadaannya secara faktual ada, namun identitasnya dibedakan. Pembedaan identitas inilah yang memicu peminggiran dan diskriminasi, sehingga hak-hak yang seharusnya diperoleh sebagaimana penganut agama yang diakui resmi pemerintah tidak diperoleh. Maka dari itu, pesan dalam tayangan 'Keadilan untuk Para Penghayat' ini ingin menyampaikan bahwa sekedar pengetahuan multikultural saja belum cukup, perlu ada kesadaran yang mengejawantah dalam kehidupan keseharian (Muchimah dan Ulum, 2020).

Selain itu, tayangan ini juga menyoroti ada indikasi krisis toleransi dalam kehidupan berbangsa dan bernegara. Krisis tersebut justru dimulai dari para elit agama dan politik, bukan dari golongan awam yang berada di masyarakat akar rumput. Dalam konteks kepentingan, penganut penghayat kepercayaan lokal memang cenderung dirugikan, baik dalam hal material, kebudayaan, dan ajaran yang telah dijalankan selama berpuluh-puluh tahun.

Jika ditinjau dalam konteks narasi sejarah keberadaan manusia, dinamika kejayaan dan kemunduran, penemuan, dan munculnya berbagai disiplin keilmuan serta peradaban adalah fakta bahwa sejarah manusia itu berbicara tentang sejarah keragaman dan perbedaan (Al Makin, 2017). Sejarah manusia berisi entitas-entitas yang beragam, meski di satu sisi konflik antar entitas tersebut masih berlangsung sampai saat ini. Namun konflik tersebut dimaknai sebagai bagian dari dinamika. Jika faktanya seperti itu, maka toleransi sebagai pengikat hubungan antar 
entitas menjadi penting untuk diimplementasikan. Tayangan ini secara tidak langsung mengajak konsumen untuk berpikir ulang bahwa toleransi yang dilakukan selama ini belum melibatkan para penganut penghayat kepercayaan lokal.

\section{Simpulan dan Saran}

Di Indonesia, selain enam agama yang resmi diakui oleh pemerintah terdapat ratusan kelompok penghayat kepercayaan lokal yang tumbuh subur dan masih tetap eksis sampai hari ini. Pada masa Orde Baru, kelompok penghayat kepercayaan lokal dianggap sebagai ateis dan berafiliasi dengan Partai Komunis Indonesia (PKI) jika tidak beralih ke agama yang telah diakui resmi pemerintah. Konteks historis ini menjadi pemicu perlakuan diskriminasi yang dialami oleh para penganut penghayat kepercayaan lokal.

Di sisi lain, keberadaan media menjadi instrumen penting dalam mendistribusikan sebuah informasi. Salah satu media itu adalah Metro TV. Di dalamnya terdapat program Melawan Lupa yang orientasinya memproduksi tayangan dengan muatan narasi tandingan yang berbeda dengan narasi-narasi yang ada pada umumnya, termasuk narasi tayangan tentang penghayat kepercayaan lokal. Tayangan ini dianalisis menggunakan teori semiotika Roland Barthes dengan melihat makna denotasi dan konotasinya pada beberapa adegan seperti pakaiannya, foto Kartu Tanda Penduduk (KTP) yang kolom agamanya dikosongi, kondisi pendidikan anakanak penghayat kepercayaan lokal, dan ritual penghayat kepercayaan lokal. Setelah mengetahui kedua makna dari semua adegan itu, kemudian dapat ditemukan kepentingan apa yang ada dibalik tayangan tersebut.

Adapun hasilnya, program Melawan Lupa di Metro TV yang memproduksi tayangan 'Keadilan untuk Para Penghayat' memiliki dua kepentingan yang saling berkaitan. Kepentingan pertama ingin menegaskan bahwa kesadaran multikultural itu perlu untuk diejawantahkan dalam kehidupan keseharian. Selain itu, penghormatan atas entitas-entitas yang serba multi ini juga penting dilakukan melalui implikasi toleransi. Sebab seakan-akan toleransi ini hanya diberlakukan diantara agama yang resmi diakui pemerintah, tanpa melibatkan para penganut penghayat kepercayaan lokal.

\section{Daftar Pustaka}

Al Makin. 2017. Keragaman dan Perbedaan; Budaya dan Agama dalam Lintas Sejarah Manusia. Yogyakarta: Suka Press

Baso, Ahmad. 2006. NU Studies; Pergolakan Pemikiran antara Fundamentalisme Islam dan Fundamentalisme Neo-Liberal. Jakarta:Erlangga

Budijanto, Oki Wahyu. 2016. "Penghormatan Hak Asasi Manusia Bagi Penghayat Kepercayaan di Kota Bandung".Jurnal $H A M, 7(1)$

Gardanita, Galuh Indira dan Hananto Widodo. 2020. "Analisis Yuridis Terhadap Identitas Penghayat Kepercayaan pada Kolom Agama KTP Elektronik”, Novum Jurnal Hukum, 7(1)

Gunawan, Imam. 2013. Metode Penelitian Kualitatif. Jakarta: Bumi Aksara

Hendro, Eko Punto. 2020."Simbol: Arti, Fungsi, dan Implikasi Metodologisnya". Endogami: Jurnal Ilmiah Kajian Antropologi, 3(2) 
Humaidi, M. Wildan. 2020. "Politik Hukum Mahkamah Konstitusi Atas Rekognisi Penghayat Kepercayaan dalam Kontestasi Politik Kewargaan Indonesia". Al Daulah Jurnal Hukum Pidana dan Ketatan, 9(1)

Laman website, https://www.metrotvnews.com/program/ melawan-lupa

Moelong, Lexy J Moelong. 2014.Metode Penelitian Kualitatif. Bandung: PT Remaja Rosdakarya

Muchimah dan Muh. Bahrul Ulum. 2020. "Implementasi Putusan Mahkamah Konstitusi tentang Hak Konstitusi Bagi Penganut Kepercayaan terhadap Tuhan Yang Maha Esa”.Volksgeist Jurnal Ilmu Hukum, 3(1)

Parekh, Bhikhu. 2012.Rethinking Multiculturalism Keberagaman Budaya dan Teori Politik. Yogyakarta: Penerbit Kanisius

Purwanto, Hadi dan Inyiak Ridwan Muzir (ed). 2018.Roland Barthes Mitologi. Yogyakarta: Kreasi Wacana

Riady, Ahmad Sugeng. 2020. "Tanda Religiusitas Waria Dalam Media (Kajian Semiotika Roland Barthes terhadap Tayangan Pahlawan Waria dari Yogyakarta CNN Indonesia)".Jurnal Ilmiah Sosiologi Agama (JISA), 3(1)

Santosa, Iman Budhi. 2012.Spiritualitas Jawa; Sejarah, Laku, dan Intisari Ajaran. Yogyakarta: Memayu Publishing

Soehada, Moh. 2014. Fakta dan Tanda Agama, Suatu Tinjauan SosioAntropologi. Yogyakarta: Fakultas Ushuluddin dan Pemikiran Islam Universitas Islam Negeri Sunan Kalijaga Yogyakarta bekerja sama dengan Diandra Pustaka Indonesia

Sofia, Adib. 2017. Metode Penulisan Karya Ilmiah. Yogyakarta: Bursa Ilmu 
(Halaman ini sengaja di kosongkan untuk keperluan tata letak)

Orasi: Jurnal Dakwah dan Komunikasi | Volume 12, No. 2, Desember 2021 